\title{
Effect of Landscape Control on the Spatiotemporal Variability of Riverine Chromophoric Dissolved Organic Matter
}

\author{
Guangyi Mu${ }^{1}$, Sijia $\mathbf{L i}^{2 *}$ \\ ${ }^{1}$ Grassland Science Institute, Life Science College, Northeast Normal University, Chang Chun, \\ People's Republic of China \\ ${ }^{2}$ Natural Disaster Research Institute, Environment College,Northeast Normal University, \\ Chang Chun, People's Republic of China
}

Received: 22 June 2017

Accepted: 2 January 2018

\begin{abstract}
An increase in the release of sewage discharge and stream ecosystem degradation is contributing to increased chromophoric dissolved organic matter (CDOM) in the Yinma River Watershed, which is a polluted watershed of the Songhua River. This study involves the spatiotemporal characterization of CDOM, CDOM-DOC relationships, and the influence of environmental factors (e.g., natural geographical and anthropogenic activities). Riverine waters showed higher $a_{\text {CDOM }}$ (335) and DOC concentrations in the spring and autumn than in the summer, and positive correlations were found between the $a_{\text {CDom }}(335)$ and DOC concentrations in the summer $(r=0.90,2$-tailed, $p<0.01)$ and autumn $(r=0.58$, 2-tailed, $p<0.01)$. Storms in May 2016 affected DOC flux from terrestrial ecosystems into the stream, and the CDOM-DOC relationship in the spring. Environmental factors such as water quality, precipitation, soil, gradient, land-use, and GDP could have affected the optical properties of CDOM (DOC). Gradient was correlated with the optical properties (2-tailed, $p<0.05)$ of CDOM. Types of land-use, pollutant discharge from point sources, and GDP $(\mathrm{r}=0.58,2$-tailed, $p<0.05)$ affected the composition and creation of CDOM (DOC). The correlations among CDOM absorption parameters, gradient, and GDP were driven by samples that were related to regional terrestrial and anthropogenic pollutants. High loading of complex CDOM (DOC) inputs from anthropogenic activities combine with natural influences and constitute a challenge for $\mathrm{CDOM}$ (DOC)-derived pollution treatment, and treatment of pollution in the watershed.
\end{abstract}

Keywords: chromophoric dissolved organic matter, polluted rivers, environmental factors, optical characteristic

*e-mail: lisj983@nenu.edu.cn 


\section{Introduction}

In natural surface waters, dissolved organic matter (DOM) is an important driver of ecosystem functions and forms the largest pool of organic matter [1]. Chromophoric dissolved organic matter (CDOM), which represents the optically active fraction of DOM, is compositionally complex [2]. CDOM levels could potentially be estimated via remote sensing, which has the advantages of being time and cost efficient [3]. Significant linear relationships between CDOM and dissolved organic carbon (DOC) have recently been observed in various lakes, estuaries, and coastal waters [3-4]. The optical properties of CDOM were used as a proxy for DOC concentration, which relies on an accurate characterization of the CDOMDOC relationship. Rivers and streams connect terrestrial and aquatic ecosystems from the land to the ocean, and understanding riverine CDOM (DOC) dynamics is key to identifying the roles of these ecosystems in global carbon cycling.

The flux of CDOM (DOC) into streams and rivers appears to be controlled by a number of interacting hydrological [5], geological [6], biological [7], and abiotic factors (i.e., photo-degradation and exchange with particulate organic matter and minerals). In coastal environments, CDOM and DOC behaviors are controlled by terrestrial discharges due to modest mixing along the salinity gradient. In inland rivers and streams, different factors control the concentration and physiochemistry of CDOM (DOC), showing significant complex spatial and temporal characteristics [5-7]. Song et al. (2013) [8] reported average DOCs from fresh and brackish waters, which were $5.63 \mathrm{mg} \mathrm{L}^{-1}$ (fresh water) and $15.33 \mathrm{mg} \mathrm{L}^{-1}$ (brackish water) across the semi-humid/ semi-arid Songnen plain in China. Zhou et al. (2015) [9] found that average DOC concentrations in Meiliang Bay, Lake Taihu, increased from August $(2.2 \mathrm{mg} / \mathrm{L})$ to September $\left(4.7 \mathrm{mg} \mathrm{L}^{-1}\right)$, and were maintained until the following January. Studies in the Arctic have noted that low concentrations of CDOM were observed in the permafrost zone, while high concentrations were found in coniferous forest areas [10]. Agricultural practices have been shown to have contrasting effects on stream DOM [11], while others have ascribed watershed-scale DOC exports to DOC-rich forest floors and surface-soil layers in riparian or wetland locations [12]. Rainfall events or snowmelt seasons also contribute to high concentrations and loading of DOC in stream waters [13]. These environmental factors (e.g., water quality, watershed morphology, soil, vegetation, land-use, rainfall) and landscapes are likely to affect CDOM variation and instream processing by partially affecting hydrological connections between landscape units and their receiving waters [10-13].

Absorption can be used as a potentially viable approach to trace and detect different sources and abnormal changes of DOM in water bodies. Physiochemical properties of CDOM, such as absorption coefficients, average molecular weight $\left(E_{250: 365}\right)$, spectral slope $\left(S_{275-295}\right)$, and specific ultraviolet absorbance $\left(\mathrm{SUVA}_{254}\right)$ [8], are important indicators for understanding the mobility, degradability, and bioavailability of DOM, and act as tracers for identifying DOM sources and flow paths. Improved quantitative understanding of how the environmental factors of catchments can affect spatiotemporal CDOM, based on optical parameters, will be beneficial for understanding biogeochemical carbon cycles and managing water sources in regional watersheds.

The accumulation of heavy metals in sediments and bio-accumulation of benthic organisms were recently noticed in the Songhua fluvial system [14]. About 100 tons of benzene was discharged into Songhua due to chemical plant explosions in Jilin in 2005 [15]. Since the Songhua became polluted, there is a potential impact on the Russian population living downstream. The Yinma River Watershed, the most polluted of the Songhua's watersheds according to the 2014 China Environmental State Bulletin) supplies large amounts of organic matter to the Songhua fluvial system [16]. Quantitative estimation and monitoring of CDOM in highly polluted riverine environments provide an early warning of drinking water supply contamination. In addition, the watershed is located in agricultural areas of northeastern China, and increased fertilizer contact with allochthonous DOM leads to greater terrestrial CDOM input, which results in varying spectroscopic characteristics. We aimed to assess how landscapes affect CDOM and DOC patterns in receiving streams, considering how this is related to wide spatial and temporal variability loads in ecosystems. Our detailed objectives were to: 1) investigate and evaluate seasonal and spatial CDOM characteristics, 2) quantitatively and qualitatively understand the influence of environmental factors (e.g., water quality morphology, land-use, soils, rainfall, and socioeconomic data) on riverine CDOM, and 3) understand and discuss the role of human activities on freshwater DOM cycling. The results could aid regulators and policy managers in improving water quality in highly polluted watersheds.

\section{Material and Methods}

\section{Study Area}

The Yinma River watershed $\left(124^{\circ} 58^{\circ}-126^{\circ} 24^{\circ} \mathrm{E}\right.$, $43^{\circ} 02^{\circ}-44^{\circ} 53^{\circ} \mathrm{N}$ ), an important tributary of the Songhua fluvial system, is located in the center of Jilin Province, China (Fig. 1). The area of the watershed is about $1.74 \times 10^{4} \mathrm{~km}^{2}$ and includes two main rivers: the Yinma and the Yitong [16]. This watershed has a typical northern temperate zone and continental monsoon climate, with a frozen period of about 150 days. The mean annual temperature is $5.3^{\circ} \mathrm{C}$, and yearly average precipitation ranges from 370 to $668 \mathrm{~mm}$ [16]. The Yinma River originates in the southeast of Yitong, and merges with the Yitong River in Nong'an, flowing into the second 


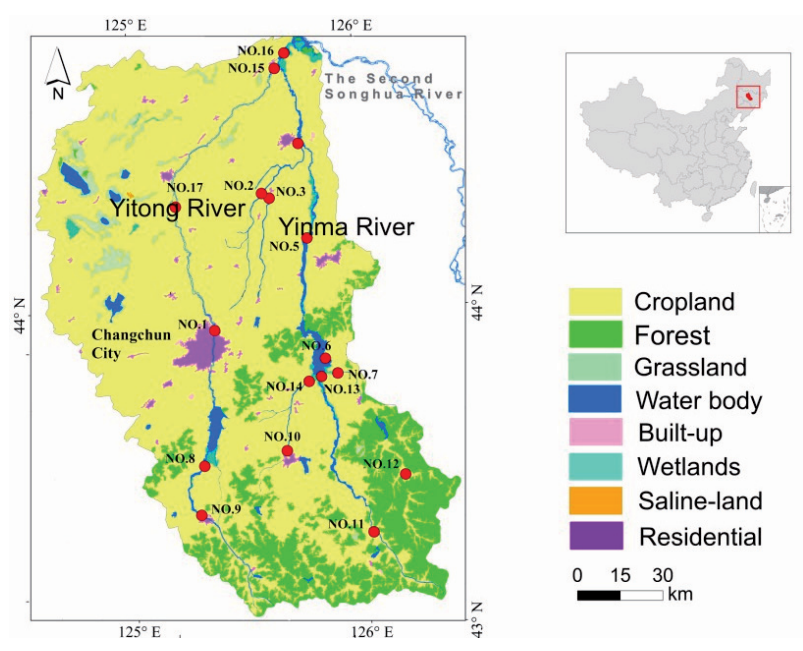

Fig. 1. Study region and sampling stations of study area, including Yitong River (YT, 5 sampling stations), Yinma River (YM, 11 sampling stations), and No.16 in the confluence of the Yinma and Yitong rivers.

Songhua fluvial system. The main tributaries of the watershed include the Wukai, Chalu, and Shuangyang rivers.

\section{Water Sample Collection}

Fifty-one river water samples were taken from the surface layer $(0-0.2 \mathrm{~m})$ at 17 sites in the watershed between August 19-22 and October 30, 2015, and May 8, 2016 (Fig. 1). The data sets collected in August and October could be published in Li et al. (2016) [16]. These samples were constant locations according to Li et al. (2016) [16]. A Perspex water sampler and Niskin bottles were rinsed with Milli-Q water before collection, and then rinsed by the water samples. Approximately $2.5 \mathrm{~L}$ of water was collected for each sample at each site $(0-20 \mathrm{~cm})$, and immediately analyzed on board the boat, or stored in the dark at $4^{\circ} \mathrm{C}$, in acidcleaned, pre-combusted amber bottles for laboratory analysis.

\section{Water Quality Determination}

To prevent pigments from denaturalization, water samples were immediately filtered under a low vacuum. The concentrations of Chl-a were determined with a UV spectrophotometer (Shimadzu, UV-2006 PC) at $664 \mathrm{~nm}, 647 \mathrm{~nm}, 630 \mathrm{~nm}$, and $750 \mathrm{~nm}$. Total suspended matter (TSM), inorganic suspended matter (ISM), and organic suspended matter (OSM) were determined by gravimetrical analysis. Detailed measurements of Chl-a, TSM, ISM, and OSM could be found in Song et al. (2013) [8]. DOC samples were acidified to a $\mathrm{pH}$ of 2 with concentrated $\mathrm{HCl}(100 \mu \mathrm{L}$ of $2 \mathrm{~N})$ to remove inorganic carbon and were then analyzed with a total organic carbon analyzer (Shimadzu, TOC-VCPN) using high-temperature catalytic oxidation $\left(680^{\circ} \mathrm{C}\right)$. Potassium hydrogen phthalate was used as a reference for this. DOC concentration was measured by subtracting the dissolved inorganic carbon (DIC) from total dissolved carbon (TDC). $\mathrm{pH}$ was measured using a PHS-3C $\mathrm{pH}$ meter at room temperature $\left(20 \pm 2{ }^{\circ} \mathrm{C}\right)$. References for the environmental quality standards for surface water (GB3838-2002, China) [17], dissolved oxygen (DO) (iodometry), COD (dichromate), ammonia nitrogen $\left(\mathrm{NH}_{3}-\mathrm{N}\right)$ (Nessler's reagent colorimetry), iron (Fe) (flame atomic absorption spectrometry), manganese (Mn) (potassium periodate spectrophotometric), zinc (Zn) (atomic absorption spectrometry), mercury (Hg) (atomic absorption spectrophotometry), and hexavalent chromium $\left(\mathrm{Cr}^{6+}\right)$ (diphenylcarbohydrazide spectrophotometric) were also determined.

\section{Measuring CDOM Absorbance}

All samples were filtered under a low vacuum; first through a pre-combusted Whatman GF/F (1825-047) filter $(0.7 \mu \mathrm{m})$, and then through a pre-rinsed $25 \mathrm{~mm}$ Millipore membrane cellulose filter $(0.22 \mu \mathrm{m})$ into glass bottles. Absorbance of the filtrate was measured between $200 \mathrm{~nm}$ and $800 \mathrm{~nm}$ at $1 \mathrm{~nm}$ intervals using a Shimadzu UV-2600 spectrophotometer, with Milli-Q water as a reference [16]. The absorption coefficient $\left(a_{\mathrm{CDOM}}\right)$ was calculated from the measured water optical density (OD), and more details could be found in Li et al. (2016) [16]. In order to eliminate the internal backscattering, the absorbance over 740 to $750 \mathrm{~nm}$ was assumed to be zero $[8,16]$. CDOM spectral slope coefficient $S_{275-295}$ was calculated using a nonlinear fit of an exponential function over 275 to $295 \mathrm{~nm}[8,16]$.

CDOM, total particulates (non-algal and phytoplanktonic), and pure water are four components that absorb and scatter solar radiation through water bodies [3]. To determine the contributions of these three components, non-algal $a_{\mathrm{d}}(\lambda)$ and phytoplanktonic absorption $a_{\mathrm{ph}}(\lambda)$ need to be measured. Water samples were filtered under a low vacuum through a precombusted Whatman GF/F (1825-047) filter (0.7 $\mu \mathrm{m})$ following the quantitative filter technique (QFT) [18]. Total particulate absorbance was then measured between $400 \mathrm{~nm}$ and $700 \mathrm{~nm}$ using a Shimadzu UV2600 spectrophotometer with a blank filter as a reference. Non-algal particles were bleached with $0.1 \%$ sodium hypochlorite, and the absorbance of phytoplankton was calculated by subtracting non-algal particles from total particulate subtract. The total absorption coefficient is the sum of $a_{\mathrm{d}}(\lambda), a_{\mathrm{ph}}(\lambda), a_{\mathrm{CDOM}}(\lambda)$, and $a_{\mathrm{w}}(\lambda)$, where $a_{\mathrm{w}}(\lambda)$ represents pure water absorption derived from Smiths et al. (1981) [19]. The specific UV absorbance (SUVA) values of the samples were calculated by multiplying DOC concentration-normalized UV absorbance at $254 \mathrm{~nm}$ by a factor of 100 (i.e., $\left.100 \times \mathrm{SUVA}_{254} / \mathrm{DOC}\right)[8,16]$. According to Lambert et al. (2015) [6], it is necessary to correct SUVA $_{254}$ due to the influence of $\mathrm{Fe}$ absorbance at $254 \mathrm{~nm}$. Weishaar et al. (2003) [20] reported that an $\mathrm{Fe}$ concentration 
of $0.02 \mathrm{mg} \mathrm{L}^{-1}$ produces an additive absorbance of $0.002 \mathrm{~cm}^{-1}$. The corrected $a_{\mathrm{CDOM}}(254)$ was used to calculate $\mathrm{SUVA}_{254} . E_{250: 365 \text { was }}$ the ratio of specific UV absorption coefficient at $254 \mathrm{~nm}$ and $365 \mathrm{~nm}$.

\section{Remote Sensing Data}

(1) DEM data were obtained from the shuttle radar topography mission (SRTM) data sets. In this study, SRTM-1, provided by the Computer Network Information Center, Chinese Academy of Sciences (http://datanirror. csdb.cn), with a spatial resolution $30 \mathrm{~m}$, was selected to extract gradient, aspect, and riverine profiles. (2) Soil data sets of a 1:1000000 scale were obtained from the Harmonized Word Soil Database (HWSD) version 1.1, with a spatial resolution of $1000 \mathrm{~m}$. The dataset was provided by the Environmental and Ecological Science Data Center for West China, National Natural Science Foundation of China (http://westdc.westgis.ac.cn), and the soil classification system is FAO-90 (China). (3) The land-use data images were obtained from free Landsat OLI. There are two images from the Yinma river watershed, and the satellite tracking numbers are 118, 29 and 118, 30. These images were acquired to avoid clouds. The dates of the final images are April 3 and June 16, 2015. We interpreted the remote sensing images based on true color bands (bands 4, 3, and 2). Landuse was classified by geographical knowledge and visual interpretation. The land-use types assigned were saline land, wetlands, water, roads, residential, built-up, grassland, forest, dry field, and paddy field.

\section{Meteorological Data}

Meteorological data were obtained from the National Climate Center (NCDC) of the National Oceanic and Atmospheric Administration (NOAA). The meteorological data are free to acquire on their website (ncdc.noaa.gov), and they contain precipitation, etc. The average pixel values of a $3 * 3$ window, centered at each meteorological station, were extracted. Meteorological data from Changchun Station were used to calculate average temperature and precipitation.

\section{Socioeconomic Data}

Socioeconomic data from the Resources and Environment Science Data Center, Chinese Academy of Sciences (resdc.cn) contain gross domestic product (GDP) and population for 2011. Grid data of GDP and population data take the county as the unit. Considering the GDP or population-geographic differentiation regularity of natural elements, we made spatial interpolation in the Yinma River watershed, and GDP and a population distribution map can be made with the $1 \times 1 \mathrm{~km}$ grid data.

\section{Statistical Analysis}

Statistical analyses (e.g., regression and correlation analysis) were conducted using SPSS 16.0. When the $p$ values were less than or equal to 0.05 or 0.01 , the difference is considered to be statistically significant. Spatial analysis was conducted using ArcGIS 10.2. Redundancy analysis (RDA) was used to analyze the influence of water quality on CDOM absorption parameters using Canoco 4.5.

\section{Results and Discussion}

\section{Optical Characteristics of CDOM}

\section{CDOM Absorption Parameters}

The CDOM absorption coefficient at specific wavelength, e.g., $a_{\mathrm{CDOM}}$ (335) and $a_{\mathrm{CDOM}}$ (440), has been used as a surrogate for colored DOM or CDOM concentrations [21]. The seasonal average CDOM absorption coefficients are shown in Table 1; a higher CDOM concentration was observed in the spring. High SUVA $_{254}$ values indicate aquatic systems with large input from vascular plants, and allochthonous sources dominating organic matter content [20, 22]. Conversely, low values indicate more autochthonous (algal and microbial) sources. The SUVA ${ }_{254}$ measurements were $1.7 \pm 0.8 \mathrm{~L} \mathrm{~g} \mathrm{C}^{-1} \mathrm{~m}^{-1}, 4.0 \pm 1.4 \mathrm{~L} \mathrm{~g} \mathrm{C}^{-1} \mathrm{~m}^{-1}$, and

Table 1. CDOM absorption parameters of samplings collected in riverine wate.

\begin{tabular}{|c|c|c|c|c|c|c|}
\hline \multirow{2}{*}{ Indices } & \multicolumn{2}{|c|}{ Spring } & \multicolumn{2}{c|}{ Summer } & \multicolumn{2}{c|}{ Autumn } \\
\cline { 2 - 6 } & Avg \pm SD. & Min-Max & Avg \pm SD. & Min-Max & Avg \pm SD. & Min-Max \\
\hline$a_{\mathrm{CDOM}}(335)$ & $6.6 \pm 1.5$ & $4.4-9.5$ & $5.5 \pm 3.5$ & $0.3-10.6$ & $0.4-12.3$ \\
\hline$a_{\mathrm{CDOM}}(440)$ & $0.6 \pm 0.3$ & $0.02-1.0$ & $0.6 \pm 0.6$ & $0-1.7$ & $0.8 \pm 0.9$ \\
\hline $\mathrm{SUVA}_{254}$ & $1.7 \pm 0.8$ & $0.6-3.2$ & $4.0 \pm 1.4$ & $1.6-6.3$ & $2.3 \pm 0.8$ \\
\hline$E_{250: 365}$ & $7.8 \pm 0.9$ & $6.6-9.7$ & $11.7 \pm 11.5$ & $0-38.7$ & $6.4 \pm 2.8$ \\
\hline$S_{275-295}$ & $0.0078 \pm 0.0006$ & $0.0068-0.0090$ & $0.0089 \pm 0.0020$ & $0.0069-0.0147$ & $0.0082 \pm 0.0016$ & $0.0066-0.0123$ \\
\hline
\end{tabular}

Units of the absorption coefficients of CDOM are $\mathrm{m}^{-1}, \mathrm{~S}_{275-295}$ is $\mathrm{nm}^{-1}$ and the unit $\mathrm{SUVA}_{254}$ is $\mathrm{L} \mathrm{mg} \mathrm{C}^{-1} \mathrm{~m}^{-1}$; the results of spring and summer can be found in Li et al. (2016) [16]. 
$2.3 \pm 0.8 \mathrm{~L} \mathrm{~g} \mathrm{C}^{-1} \mathrm{~m}^{-1}$ in the spring, summer, and autumn, respectively. This indicates that allochthonous sources dominated the organic matter content of river water in the summer [16]. The high SUVA $_{254}$ value in the summer was also associated with lower bioavailability. $E_{250: 365}$ and $S_{275-295}$ are related to aromatic hydrocarbon content and can trace the molecular size of CDOM [8, 22]. Increasing $E_{250: 365}$ values indicates a decrease in CDOM aromaticity and molecular weight, and $S_{275-295}$ values were inversely proportional to CDOM molecular weight, with a steeper spectral slope indicating decreasing aromaticity and a shallower spectral slope indicating increasing aromatic content $[8,22]$. Higher average $E_{250: 365}(11.7 \pm 11.5)$ values were observed in the summer than in the spring (7.8 \pm 0.9$)$ and autumn (6.4 \pm 2.8$)$ (Table 1). Similarly, the average $S_{275-295}$ value was $0.0078 \pm 0.0006 \mathrm{~nm}^{-1}$ in the spring, $0.0089 \pm 0.0020 \mathrm{~nm}^{-1}$ in the summer, and $0.0082 \pm 0.0016 \mathrm{~nm}^{-1}$ in the autumn, respectively. This indicates a decrease in aromatic compounds and percentages of fulvic acid with a low molecular weight in CDOM in the summer [16].

\section{Relative Contributions of CDOM Absorption}

Differences in the contributions of optically active substances to total absorption could influence maximum photosynthetic rate and determine the photochemical mineralization of DOC [23]. There was a noticeable seasonal difference in the relative contributions of CDOM at $440 \mathrm{~nm}$ (Fig. 2), and the absorption of nonalgal particles greatly influenced total non-water light absorption in river water. High loads of suspended matter prevent phytoplankton growth due to light limitations [16]. The average CDOM absorption contribution to the total absorption contribution was $21.9 \%$ in the

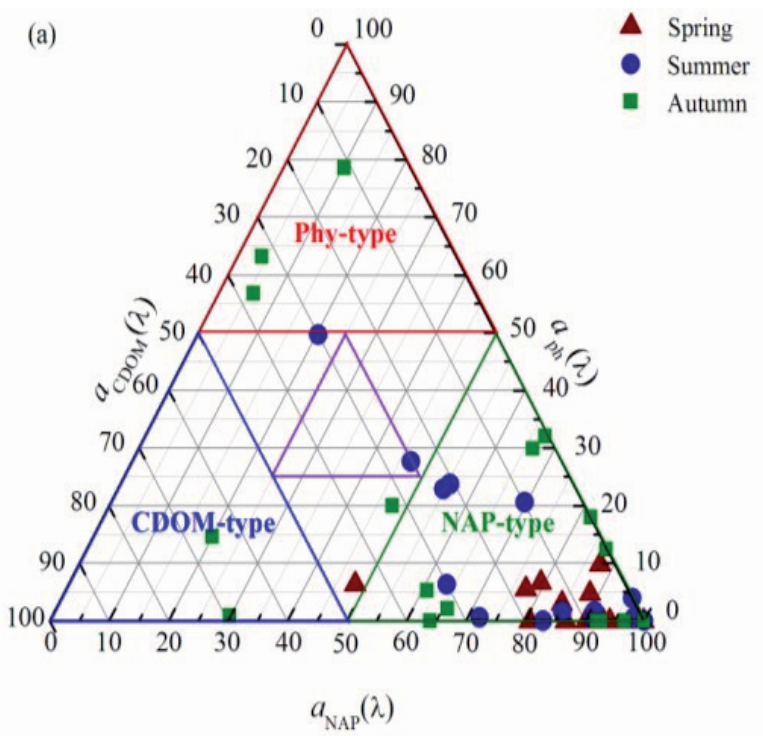

Fig. 2. Relative contributions of CDOM, phytoplankton, and non-algal particles absorption to total non-water light absorption at $440 \mathrm{~nm}$. autumn, and $10 \%$ and $12.5 \%$ in the spring and summer, respectively, according to the results from Li et al. (2016) [16]. CDOM absorption is affected by solar radiation, phytoplankton, microbial activity, and river discharge due to processes including chemical photo-bleaching, microbial degradation, and terrestrial inputs. High contribution from non-algal particles showed that the UV-photic zone for photobleaching in turbid water rarely exceeds $10 \mathrm{~cm}[16,24]$. This demonstrated that the effect of CDOM on photobleaching is inefficient, and mixing hinders its effect. According to Zhu et al. (2013)[3], more non-algal particles increase absorption and scattering contributions, which affect the derive riverine CDOM using remote sensing.

\section{Water Quality}

Seasonal TSM, ISM, OSM, DOC, and Chl-a concentrations were measured in riverine waters (Table 2). Compared with the results of Li et al. (2016) [16], the average TSM concentration in the spring (312.8 $\left.\pm 484 \mathrm{mg} \mathrm{L}^{-1}\right)$ was higher than in the summer $\left(152.2 \pm 190 \mathrm{mg} \mathrm{L}^{-1}\right)$ and autumn $\left(38.5 \pm 64.7 \mathrm{mg} \mathrm{L}^{-1}\right)$, and ISM was a large proportion of TSM. TSM concentrations associated with soil organic matter were largely affected by precipitation, types of land-use, and sediment suspension. The average Chl-a concentration followed a decreasing pattern from autumn to summer to spring comparing with Li et al. (2016) [16]. Yu et al. (2015) [25] found that high loads of suspended matter could prevent phytoplankton growth due to light limitation and microbial activity. In contrast, a higher average DOC concentration of $17.4 \mathrm{mg} \mathrm{L}^{-1}$ was observed in the spring compared to the summer $\left(5.6 \mathrm{mg} \mathrm{L}^{-1}\right)$ and the autumn (8.7 $\mathrm{mg} \mathrm{L}^{-1}$ ) (Table 2) [16]. The average DOC was higher than that of African rivers such as the Congo (10.8 $\mathrm{mg} \mathrm{L} \mathrm{L}^{-1}$ ), Tshopo (3.7 $\mathrm{mg} \mathrm{L} \mathrm{L}^{-1}$ ), and Kafue (4.3 $\mathrm{mg} \mathrm{L}^{-1}$ ) [6]. DOC concentrations in Arctic rivers such as the Kolyma are noticeably higher during the spring but lower and more stable from July-October [26]. A high DOC concentration in the spring could be related to regional flow and storm events (Fig. 7), which could release terrestrial DOM and humic acid, and that has a high molecular weight, into the river. Riverine waters have the high flow and quick exchange rates of moving water. CDOM (including fluorescent matter and components absorbing light at $254 \mathrm{~nm}$ ) was found to be resistant to bio-degradation by riverine microorganisms [27]. The fraction of readily degradable riverine DOM that was not included in CDOM was estimated to constitute between 8 and $26 \%$ of the overall DOC [27]. At $254 \mathrm{~nm}$, the reduced seasonal disparity of CDOM absorption and the larger seasonal disparity of DOC concentration could be responsible for the elevated $\mathrm{SUVA}_{254}$ in the summer and autumn; the ratio of $\mathrm{SUVA}_{254}$ is $a_{\mathrm{CDOM}}$ (254)/DOC. Consistent with results of Li et al. (2016) [16], a potential reason could be that more uncolored dissolved organic matter (UDOM) existed in riverine waters. Furthermore, algal-derived DOC had lower color 
Table 2. Seasonal water quality in the Yinma River watershed.

\begin{tabular}{|c|c|c|c|c|c|c|}
\hline \multirow{2}{*}{$\begin{array}{c}\text { Water } \\
\text { quality }\end{array}$} & \multicolumn{2}{|c|}{ Spring } & \multicolumn{2}{c|}{ Summer } & \multicolumn{2}{c|}{ Autumn } \\
\cline { 2 - 7 } & Avg \pm SD. & Min-Max & Avg \pm SD. & Min-Max & Avg \pm SD. & Min-Max \\
\hline DOC & $17.4 \pm 6.5$ & $9.7-32.5$ & $5.6 \pm 2.9$ & $2.4-14.4$ & $8.7 \pm 4.1$ & $4.3-19.1$ \\
\hline Chl-a & $11.5 \pm 15.4$ & $1.2-61.7$ & $28.3 \pm 57.2$ & $0-226$ & $30.5 \pm 46.2$ & $2.6-187.6$ \\
\hline TSM & $312.8 \pm 484$ & $13-1904$ & $152.2 \pm 190$ & $13.7-651.3$ & $38.5 \pm 64.7$ & $4-271$ \\
\hline ISM & $299.3 \pm 464$ & $9.5-1816$ & $144.7 \pm 182$ & $9.3-619.3$ & $35.3 \pm 60.9$ & $3.4-252$ \\
\hline OSM & $13.5 \pm 20.9$ & $1.7-88$ & $7.5 \pm 8.1$ & $0.3-32$ & $3.2 \pm 4.3$ & $0.6-19$ \\
\hline
\end{tabular}

Units of the DOC, TSM, ISM and OSM are $\mathrm{mg} / \mathrm{L}$, and $\mathrm{Chl}-\mathrm{a}$ is $\mu \mathrm{g} / \mathrm{L}$; the results of spring and summer could be found in $\mathrm{Li}$ et al. (2016) [16].

intensity than DOC derived from the decomposition of woody vegetation (humic-derived DOC), and DOC from anthropogenic sources (e.g., wastewater effluent) is almost uncolored $[16,28]$. This suggested that the endogenous CDOM pool was likely to be small compared to anthropogenic CDOM input into the rivers [16], consistent with CDOM absorption parameters (Table 1).

\section{Correlations between CDOM Parameters and Water Quality}

Significant linear CDOM-DOC relationships have been documented in various coastal, estuarine, riverine, and lake domains in recent years $[7-8,22,25]$. The Pearson correlation indicates a more positive correlation between $a_{\text {CDOM }}(335)$ and DOC in the summer than autumn, with $r$ values of 0.82 and 0.68 (2-tailed, $p<0.05$ ), respectively (Table 3). CDOM-DOC relationships were highly variable in inland waters due to the effects of terrigenous vgetation and non-algal particles, and the ratio is not consistent [22]. According to Li et al. (2016) [16], these results are related to changes in $\mathrm{SUVA}_{254}$ and $a_{\text {CDOM }}(\lambda)$ in different seasons and regions. When the ratios of CDOM and UDOM or CDOM and DOC were constant, an improved CDOM-DOC relationship could be found [16]. Similarly, significant correlations between $a_{\mathrm{CDOM}}(335)$, TSM, ISM, and OSM $(r>0.54 ; p<0.05$, 2 -tailed) suggest more influence from allochthonous sources in the autumn than summer. In the summer, although the correlation coefficient $r$ between the $\mathrm{CDOM}$ and Chl-a was 0.56 (2-tailed, $p<0.05$ ), a significant correlation between $E_{250: 365}$, TSM, ISM, and OSM ( $r=0.95,0.95$ and $0.83 ; p<0.01,2$-tailed) indicated that allochthonous sources affect the optical parameters of CDOM (Table 3). In the autumn, however, there was a negative correlation between $\mathrm{SUVA}_{254}$, $E_{250: 365}$, TSM, and ISM, and a positive correlation between $S_{275-296}$, TSM, and ISM (2-tailed, $p<0.05$ ).

Table 3. Pearson correlation between CDOM optical parameters and water quality concentration.

\begin{tabular}{|c|c|c|c|c|c|c|c|}
\hline Time & $\mathrm{N}$ & Parameters & DOC & TSM & ISM & OSM & Chl-a \\
\hline \multirow{4}{*}{ Spring } & 17 & $a_{\mathrm{CDOM}}(335)$ & -0.14 & -0.10 & -0.11 & -0.06 & 0.10 \\
\hline & 17 & SUVA $_{254}$ & $-.83^{* *}$ & 0.003 & 0.01 & -0.05 & 0.24 \\
\hline & 17 & $E_{250: 365}$ & -0.21 & 0.20 & 0.20 & 0.17 & 0.11 \\
\hline & 17 & $S_{275-295}$ & -0.39 & 0.11 & 0.11 & 0.08 & 0.13 \\
\hline \multirow{4}{*}{ Summer } & 17 & $a_{\mathrm{CDOM}}(335)$ & $0.82^{* *}$ & -0.46 & -0.47 & -0.34 & $0.51 *$ \\
\hline & 17 & SUVA $_{254}$ & 0.11 & -0.46 & -0.46 & -0.43 & -0.15 \\
\hline & 17 & $E_{250: 365}$ & -0.27 & $0.95^{* *}$ & $0.95^{* *}$ & $0.83^{* *}$ & -0.22 \\
\hline & 17 & $S_{275-295}$ & -0.44 & 0.04 & 0.04 & 0.02 & -0.23 \\
\hline \multirow{4}{*}{ Autumn } & 17 & $a_{\mathrm{CDOM}}(335)$ & $0.68^{* *}$ & $-0.49^{*}$ & $-0.50^{*}$ & -0.34 & 0.12 \\
\hline & 17 & $\mathrm{SUVA}_{254}$ & -0.03 & $-0.70^{* *}$ & $-0.70^{* *}$ & $-0.55^{*}$ & 0.29 \\
\hline & 17 & $E_{250: 365}$ & 0.10 & $-0.73^{* *}$ & $-0.74^{* *}$ & -0.46 & -0.005 \\
\hline & 17 & $S_{275-295}$ & -0.35 & $-0.79^{* *}$ & $0.80^{* *}$ & $0.54^{*}$ & -0.089 \\
\hline
\end{tabular}

${ }^{* *}$ correlation is siginiciant at the 0.01 level (2-tailed) and *correlation is siginiciant at the 0.05 level (2-tailed); units of the absorption coefficients of CDOM are $\mathrm{m}^{-1}, S_{275-295}$ is $\mathrm{nm}^{-1}, \mathrm{SUVA}_{254}$ is $\mathrm{L} \mathrm{mg} \mathrm{C}^{-1} \mathrm{~m}^{-1}, \mathrm{Chl}-\mathrm{a}$ is $\mu \mathrm{g} / \mathrm{L}$, and the DOC, TSM, ISM, and OSM are mg/L; the results of spring and summer could be found in Li et al. (2016) [16] 


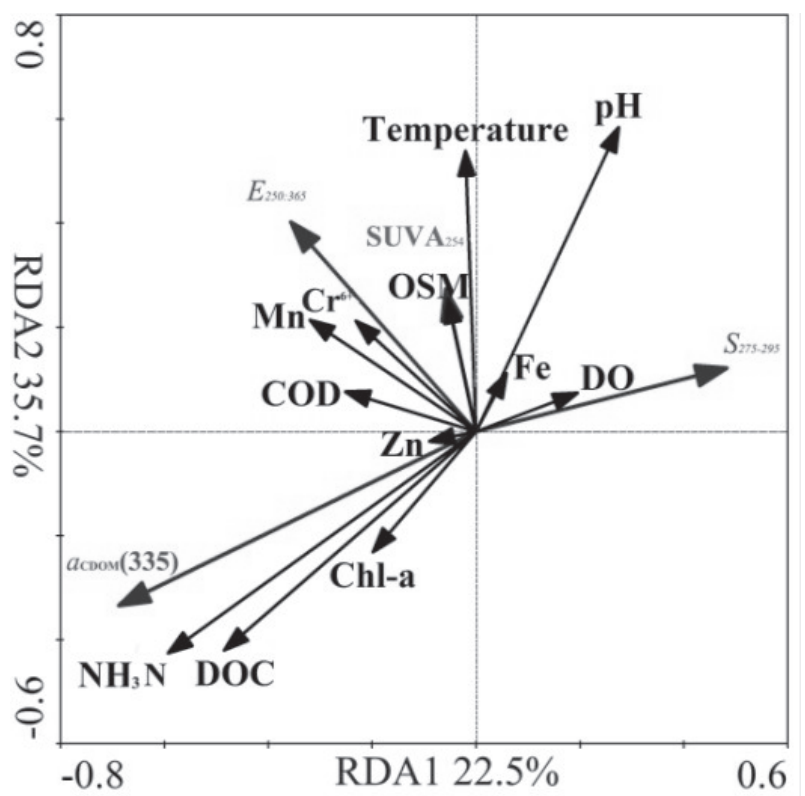

Fig. 3. RDA between the CDOM optical parameters and water quality $(\mathrm{N}=51)$; blue dots represent species variables while black dots are environmental variables.

Contrasting results of Li et al. (2016) may be caused by extreme precipitation, and there was no correlation between water quality and $\mathrm{CDOM}$ in the spring (Table 3). This indicated that allochthonous sources are overwhelmingly dominant in CDOM in dry seasons.

RDA was used to calculate the selected water quality variables, which could explain environmental variability in CDOM absorption parameters. The Monte Carlo permutation test was selected to verify the significance of constrained scheduling. The log-transformation process was performed on the original data (species and environment variables) prior to analysis to obtain normally distributed data [22]. To eliminate invalid environmental variables with lower contribution, inflation factors of variables greater than 20 and partial correlation coefficients of variables greater than 0.8 need to be deleted [22], and TSM and ISM had to be deleted in a total of 51 water samples. The relationships between the indices of CDOM, water quality, and environmental factors are shown in Fig. 3. The first two axes of the RDA explain $35.7 \%$ of the total variability in CDOM optical parameters (axis one, 22.5\%; axis two, 35.7\%). The DOC (12.1\%) and $\mathrm{NH}_{3}-\mathrm{N}(11.1 \%)$ had a strong correlation with CDOM optical parameters, followed by $\mathrm{pH}(7.8 \%)$, temperature $(6.8 \%)$, and $\mathrm{COD}(3.5 \%)$. A previous study showed that COD, NH3-N, TN, and TP accounted for $44.14 \%, 53.14 \%, 82.15 \%$, and $78 \%$ of total pollutants, respectively, in the Yinma River watershed [29].

\section{Soil}

Different soil types and properties could largely affect litter breakdown, transformation of soil organic matter, microbial activity, etc. The spatial distributions
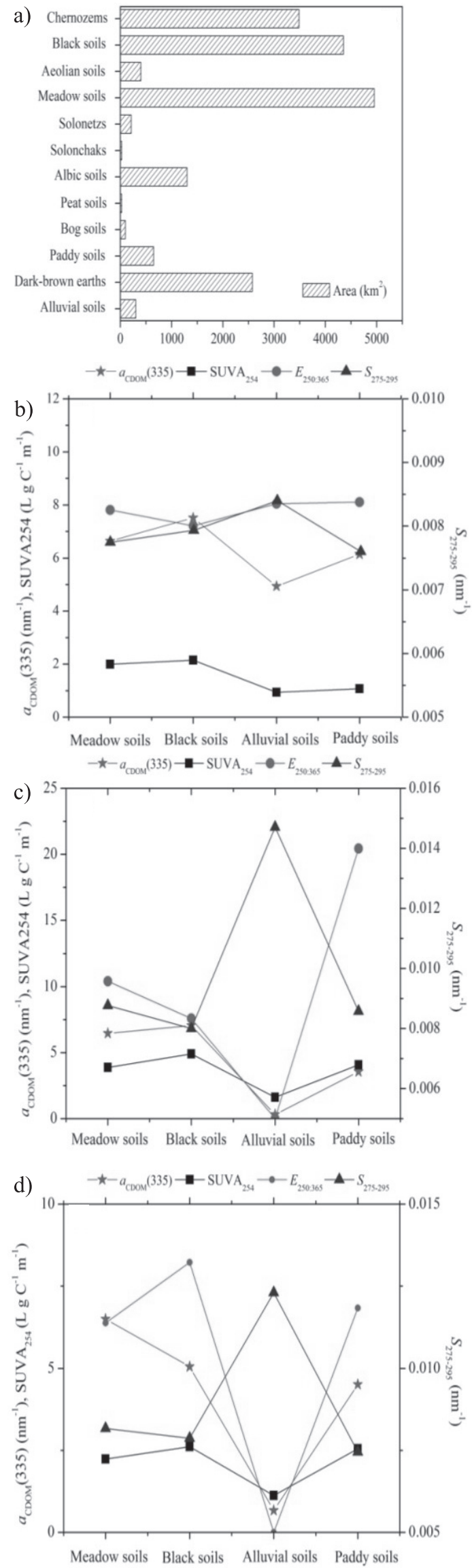

Fig. 4. The CDOM absorption parameters from different soil types in the Yinma River watershed: a) area of soil types, b) in spring 2016, c) in summer 2015, d) in autumn 2015. 
of soil types are shown in Fig. 4. All of the samples were located in four soil types: meadow, black, alluvial, and paddy. In the spring and summer higher values of $a_{\text {CDOM }}(335)$ and SUVA $_{254}$ were observed in black soils, indicating that high aromatic hydrocarbon inputs and allochthonous sources dominated organic matter content (Fig. 4). Meadow soils exhibited high $a_{\mathrm{CDOM}}(335)$ in the autumn. Regardless of season, seasonal samples in alluvial soils had the highest $S_{275-295}$ and lowest $a_{\text {CDOM }}(335), \mathrm{SUVA}_{254}$, and $E_{250: 365}$ (Fig. 4). This indicates low aromatic hydrocarbon content and low molecular weight, and that autochthonous sources dominated organic matter content.

The observed CDOM concentrations in soils are the net result of processes that release DOM, such as leaching from litter or desorption from the solid phases, and processes that remove DOM, such as adsorption or decomposition [30]. Black soil and chernozem had relatively high levels of humic acid in relation to litter; increased DOC from extended contact time in soil horizons was found in areas of high organic matter content [30]. Fertile soil was used for arable soils in the urbanizing watershed by anthropogenic activity. Fertilization with organic compounds has been found to increase water-soluble organic carbon in soil by a factor of 2.7 to 3.2, depending on the type of fertilizer added [24], which could indirectly affect water carbon levels. For many farmers in developing countries, livestock manure is an essential source of organic fertilizer. In manure-treated soils, carbon increased sharply after manure application, resulting in higher water-soluble organic matter. This was more noticeable in the sampling stations in paddy soils, which had the highest CDOM in autumn (Fig. 4). Precipitation can also significantly alter DOC concentrations and fluxes by flushing DOC adsorbed on aggregate surfaces and concentrated in subsoil horizon microspores. Excluding the physical and chemical characteristics of the soil, processes including the release and removal of CDOM also depend on external environmental factors (i.e., soil temperature and precipitation). Due to storm events, high water velocity leads to low contact time between soil horizons and the solid matrix, and creates non-equilibrium chemical and physical conditions [30]. As a result, the adsorption of DOC is diminished in mineral soil horizons. The responses of some samples to DOC concentration appear to depend on site conditions, e.g., land-use, vegetation, and human activity.

\section{Topography}

The gradient (the ratio of vertical height and horizontal width in a slope surface) ranged from $0.3^{\circ}$ to $17.68^{\circ}$ in the Yinma River watershed. There was a weak correlation between gradient, $\mathrm{SUVA}_{254}$, and $S_{275-295}$, but it was not correlated with DOC. The gradients were negatively correlated with $\mathrm{SUVA}_{254}(\mathrm{r}=-0.51 ; 2$-tailed, $p<0.05)$ in the autumn dataset (Fig. 5). A positive correlation was found between gradient and $S_{275-295}$, with a correlation coefficient of 0.51 (2-tailed, $p<0.05$ ). This indicated that when the gradient increased, riverine CDOM indicated autochthonous sources with low aromatic hydrocarbon content in the autumn. Frost et al. (2006) [32] also found that morphological parameters (watershed area, slope, drainage density, and stream length) were negatively correlated with streamwater DOC concentration, with a determination coefficient between gradient and DOC concentration of 0.24 . A watershed with a low gradient possessed significant quantities of DOM due to thicker organic horizons and longer residence times in soils [6]. A negative relationship between CDOM and gradient may reflect shallower, organic-rich soil horizons and faster movement of water through the landscape [32], which also limits the amount of DOM reaching adjacent streams. In addition, lower residence time may reduce the removal of CDOM due to photoand/or microbial degradation, and vice versa in larger watersheds. Similarly, greater gradients in the watershed could generally be associated with habitat distribution, e.g., more vegetation cover and fewer urban settlements. This relationship, however, was driven by one point in No. 12, which had the highest gradient at $17.68^{\circ}$
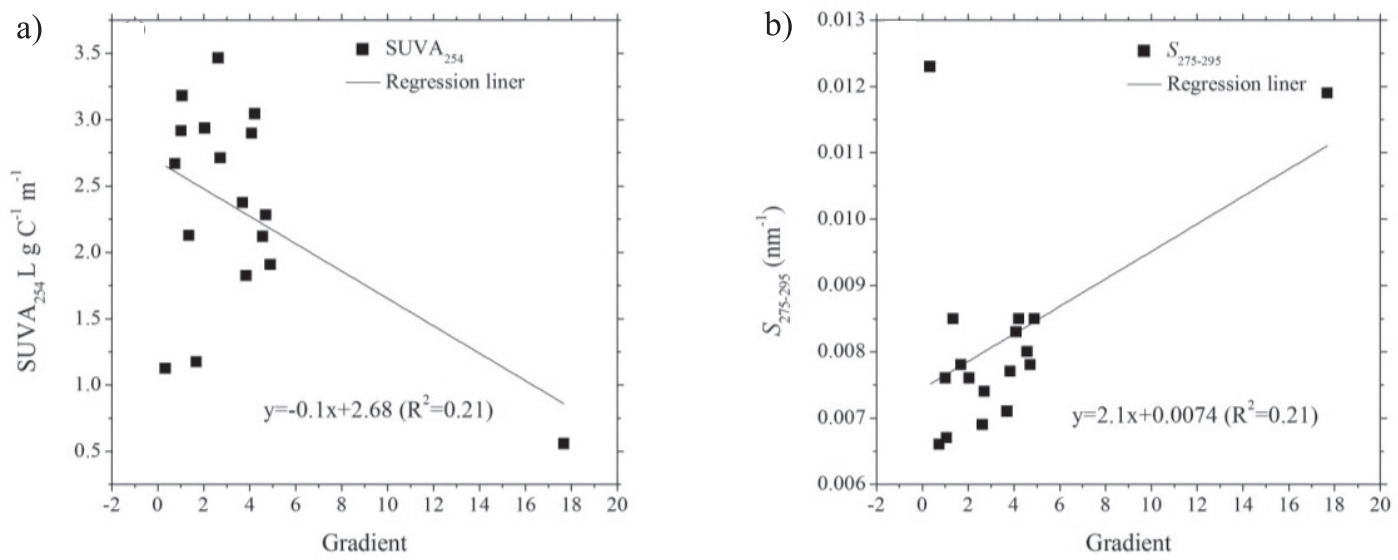

Fig. 5. Relationship between the gradient form and CDOM optical parameters: a) the gradient and riverine $\mathrm{SUVA}_{254}$ and b) the relationship between the gradient and $S_{275-295}$ in autumn. 

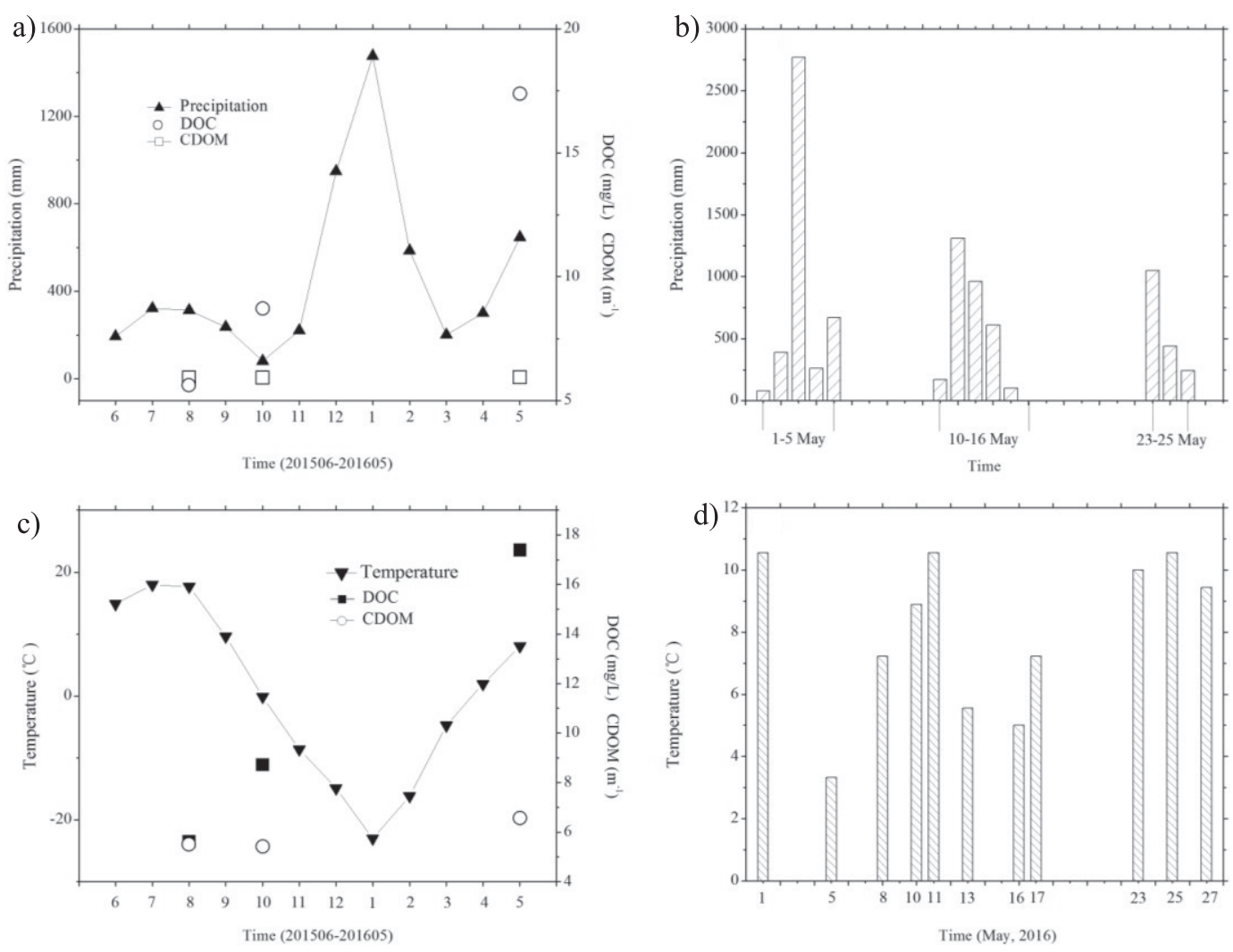

Fig. 6. Precipitation and CDOM concentrations in Yinma watershed: a) precipitation and CDOM concentrations in from June 2015 to May 2016, b) precipitation in May 2016, c) daily minimum temperature and CDOM concentrations from June 2015 to May 2016, and d) temperature in May 2016; some precipitation and daily minimum temperature values with date-tick are shown in b) and d) due to many missing values in May 2016

(Fig. 1). Then CDOM absorption parameters and water quality in No. 12 were concentrations and aromatic hydrocarbon content. When No. 12 was removed, there was no noticeable correlation (2-tailed). This indicated that topography was not the main factor in controlling riverine CDOM with a low gradient $\left(0.3-4.9^{\circ}\right)$. Other samples were limited by regional terrestrial inputs.

\section{Meteorological Factors}

In terrestrial-dominated regions, DOC generally varies seasonally in relation to the magnitude of freshwater inputs. Raymond et al. (2007) [26] reported seasonal variability of DOC in high-latitude rivers, and found that the DOC was characterized by rising concentration, significantly correlated with increased river discharge. Although the hydrological processes in streams were not monitored here, precipitation indirectly indicated the trend of CDOM. Consistent with the results of Li et al. (2016) [16], the low levels of precipitation, with high DOC and Chl-a and low TSM, were observed more in the autumn than summer (Fig. 6). These results changed with CDOM optical parameters, indicating that more allochthonous uncolored DOC (UDOC) existed in the summer than autumn. The highest average DOC and $\mathrm{CDOM}$ concentrations $\left(17.4 \mathrm{mg} / \mathrm{L}\right.$ and $\left.6.6 \mathrm{~m}^{-1}\right)$ were observed in the spring (Table 2 and Fig. 6). Storm events, which are important hydrological processes, cause various sources of DOM to enter surface waters from adjacent catchments over a short-term timescale (hours to days) due to storm flow [22]. High precipitation was observed in May 2016 (Fig. 6); on May 3, 11, and 23 in particular there were heavy storm events (annual 200-300 mm). Jiang et al. (2014) [33] found that DOC concentrations were much higher during storm events than during snowmelt seasons in both watersheds. These processes may significantly alter CDOM concentrations and composition in receiving streams, leading to uncertainty (poor correlation between $\mathrm{CDOM}$ and DOC), although rainwater generally resulted in low CDOM concentrations. Terrestrial DOM sources that were mobilized during storm flows differ from those leached during base-flow [34]. Storms could contribute to more than $50 \%$ of DOC fluxes [35]. Rapidly rising groundwater in watersheds due to storms could also contribute more CDOM and pollutants. We did not collect samples during or following heavy rain, and this work will be accomplished in future studies.

\section{Land-Use Types}

One of the most noticeable environmental changes caused by human activity is the conversion of land, e.g., clear-cutting of forest stands, afforestation, converting 
forests into arable sites, and reducing wetlands due to expanding agricultural and residential areas. The average CDOM optical parameters on congeneric land-use types, according to the sampling stations, are summarized in Fig. 7. All of the sampling stations were located in six land-use types: residential, paddy field, wetlands, dry field, forest, and saline land. In the spring, a higher $a_{\mathrm{CDOM}}(335)$ was observed in forests and wetlands (Fig. 7). The lowest $E_{250: 365}, S_{275-295}$ and SUVA $_{254}$ values, and highest $a_{\mathrm{CDOM}}(335)$, indicating an increase in aromaticity and MW of CDOM, suggest that autochthonous sources dominated organic matter content in wetlands. Similarly, allochthonous sources dominated organic matter content, with high $\mathrm{SUVA}_{254}$, in forests. An increase in aromaticity and MW was observed in saline land. In the summer, samples from forested areas showed the highest $a_{\mathrm{CDOM}}(335)$, in contrast with wetlands (Fig. 7). High SUVA $_{254}$ was also observed in forests, suggesting that allochthonous sources with high aromaticity and MW-dominated organic matter content. This result was the opposite in wetlands. In the autumn, samples in forests with the highest $a_{\mathrm{CDOM}}(335)$ showed high aromaticity and MW. Paddy fields showed lowest $a_{\mathrm{CDOM}}(335)$ and SUVA ${ }_{254}$, indicating that autochthonous sources dominated organic matter content.
We found that sampling stations located in wetlands and forests also showed relatively high CDOM concentrations. DOC transfer from peatland, through streams, was about 5-40 $\mathrm{g} \mathrm{m}^{2} / \mathrm{a}$ in the northern wetlands of Canada [36]. Anaerobic decomposition of organic matter from wetlands is less efficient than decomposition under aerobic conditions, with a higher proportion of water-soluble intermediate metabolites being released. DOC from wetland soils affected by storms or snowmelt could readily flow into streams and rivers [37]. The storms concentrated in May 2016 could have had a great impact on the inputs of DOC from wetland soil. An increasing CDOM trend was found from summer to autumn, which could be caused mainly by the decrease in precipitation [16]. More DOC could flow from forest litter into wetland soils due to leaching and microbial activity in the autumn. Wetland DOM, as a main carrier of many trace organic or inorganic pollutants, facilitates the migration or diffusion of heavy metals and hydrophobic organic pollutants in soil and water environments. In storm or snowmelt events, increased DOM could affect the growth of aquatic plants and pollute groundwater.

High nitrogen and organic matter export rates are characteristic of grasslands and forests, and land-use types around the sampling stations may be crucial to nutrient levels in water [38]. DOC concentrations were
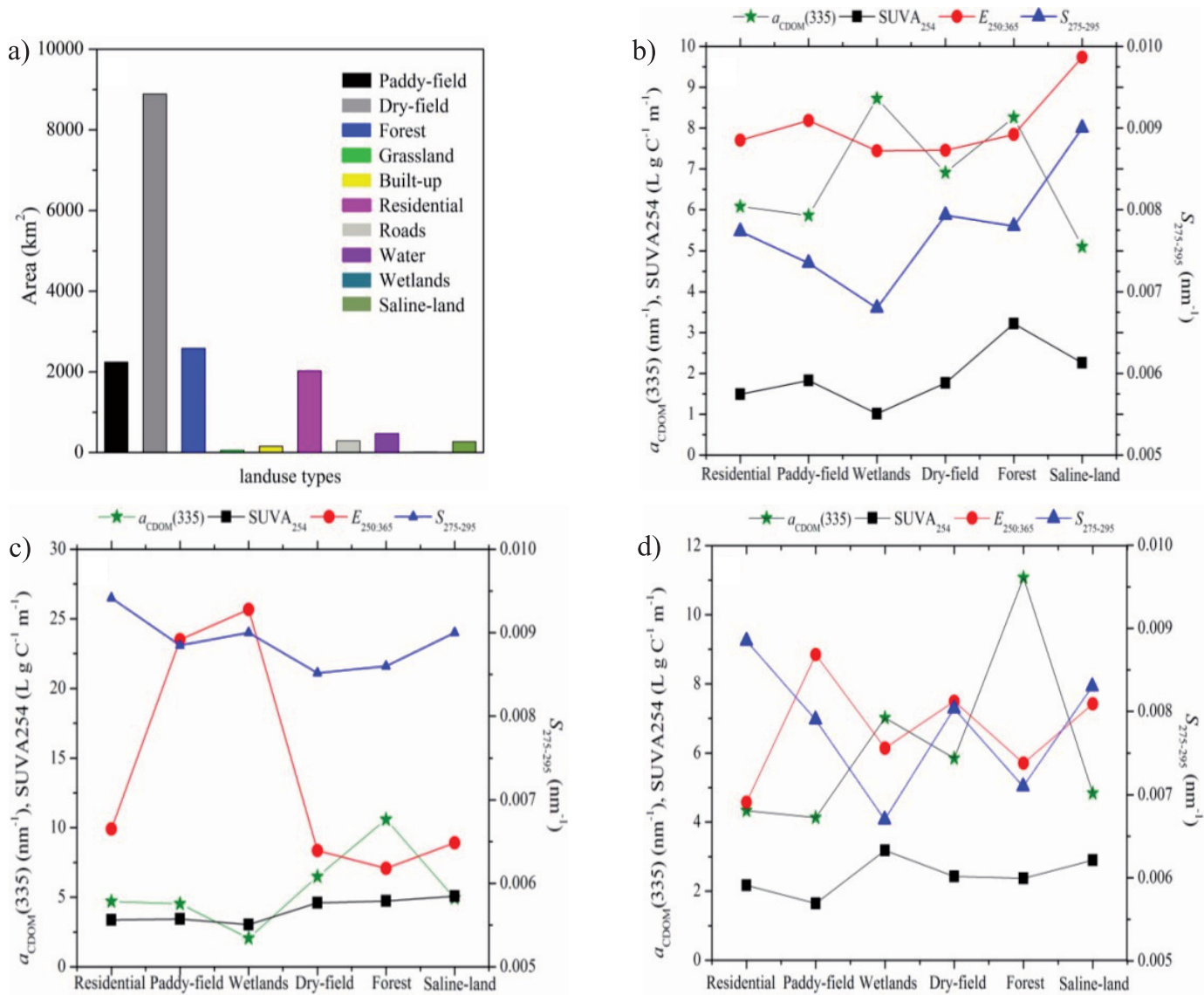

Fig. 7. The CDOM absorption parameters from different land-use types in the Yinma watershed: a) area of land-use types, b) CDOM absorption parameters from different land-use types in spring, c) CDOM absorption parameters from different land-use types in summer, and d) CDOM absorption parameters from different land-use types in autumn. 


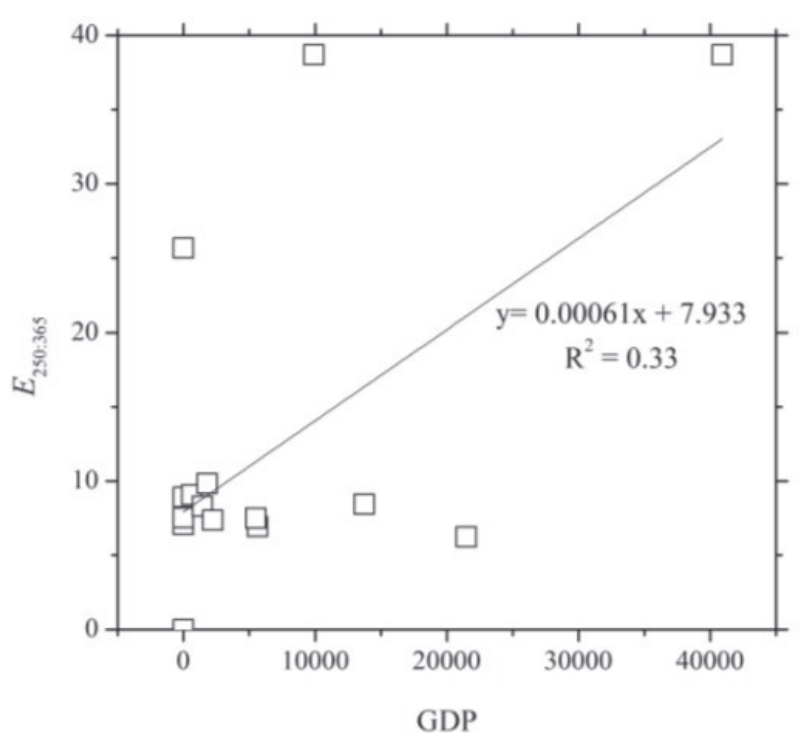

Fig. 8. Relationship between GDP and $E_{250: 365}$ in summer.

lower than that of the neighboring forest soils following 26 years of corn cultivation [39]. Wilson and Xenopoulos (2008)[40] found that rivers and streams located in southern Ontario, Canada, that flow through forests have higher DOM concentrations than those that flow through cropland. The high DOM in forest soils could be caused by increased solubility of DOM at a higher $\mathrm{pH}$, or stimulation of microorganism activity. Leaf fall in the autumn usually contributes high levels of hydrophilic, neutral DOM fractions (i.e., simple sugars and nonhumicbound polysaccharides), which could increase the DOM production rate. Additionally, saline land and paddy fields had the lowest CDOM concentrations. The differences in the relationships between CDOM and land-use types are likely a result of varying hydrology, vegetation, and soil types.

\section{Socioeconomic Data}

Population and GDP related to the strength of human activities could reveal the level of economic development in a society. A regression analysis was performed between population, GDP, and CDOM optical parameters in the watershed, but a correlation was only found between $E_{250: 365}$ and GDP in the summer ( $r=0.58$, 2-tailed, $p<0.05$ ) (Fig. 8). This result was driven by signal point, e.g., Nos. 8-9. This result indicated that there were spatial differences between samples due to terrestrial inputs. Numerous samples were taken in farmland and wetlands, and pesticide and fertilizer, household refuse, and livestock dung remained on a large area of farmland. Areas of higher GDP as related to economic output were found near the city or the reservoir. Changchun city was the center of development of the regional economy of Jilin province, and industrial waste, sewage runoff, and overpopulation all contribute to river pollution. Sewage treatment plants located in Jiutai and Dehui cities, although large, were found to be inefficient.

\section{Conclusion}

CDOM in rivers and streams were strongly related to several natural and geographical elements while predictors of anthropogenic activity levels were also likely to influence the loading, transportation, removal, and dilution of CDOM, particularly in heavily polluted rivers. Compared with published data sets from $\mathrm{Li}$ et al. (2016) [16] and samples collected in May 2016, the following conclusions were obtained:

1) In the spring and autumn, riverine waters had higher $a_{\mathrm{CDOM}}(335)$ and DOC concentrations than summer; this is related to regional riverine flow, storm events, and anthropogenic pollutants.

2) Increasing terrigenous inputs bring more UDOM from wastewater effluent, which may affect the CDOMDOC relationships in the spring. In the Yinma River watershed it is difficult to derive CDOM due to the contributions of non-particulates by remote sensing.

3) Environmental factors, e.g., water quality, precipitation, soil, land-use, gradient, and GDP, could affect the optical properties of CDOM. Although storm events affect DOC fluxes from terrestrial to stream ecosystems, these influences generally showed spatial difference (gradient and GDP), driven by a few samples.

Continuous sewage discharge from chemical factories in Changchun city, and wastewater treatment inefficiency should be improved and controlled. The Yinma watershed, with the typical heavy waters of the Songhua River, is representative of a watershed being urbanized by anthropogenic activities. High loading of complex CDOM inputs from anthropogenic activities constitutes a challenge for identifying CDOM and DOC flux.

\section{Acknowledgements}

This study was financially supported by the National Major Program of Water Pollution Control and Treatment Technology of China under grant No. 2014ZX07201- 011002 (2014-2017).

\section{Conflict of Interest}

The authors declare no conflict of interest.

\section{References}

1. GRIFFIN C.G., FREY K.E., ROGAN J., HOLMES R.M. Spatial and inter-annual variability of dissolved organic matter in the Kolyma River, East Siberia, observed using satellite imagery. Journal of Geophysical Research: Biogeosciences.116 (G3), 2011.

2. YANG W., MATSUSHITA B., CHEN J. YOSHIMURA K., FUKUSHIMA T. Application of a semianalytical algorithm to remotely estimate diffuse attenuation 
coefficient in turbid inland waters. IEEE Geoscience and Remote Sensing Letters. 11 (6), 1046, 2014.

3. ZHU W., TIAN Y.Q., YU Q., BECKER B.L. Using Hyperion imagery to monitor the spatial and temporal distribution of colored dissolved organic matter in estuarine and coastal regions. Remote Sensing of Environment. 134, 342, 2013.

4. FICHOT C.G., BENNER R. The spectral slope coefficient of chromophoric dissolved organic matter $\left(\mathrm{S}_{275-295}\right)$ as a tracer of terrigenous dissolved organic carbon in riverinfluenced ocean margins. Limnology and Oceanography. 57 (5), 1453-, 2012.

5. FINDLAY S., QUINN J.M., HICKEY C.W., BURRELL G., DOWNES M. Effects of land use and riparian flow path on delivery of dissolved organic carbon to streams. Limnology and Oceanography. 46 (2), 345, 2001.

6. LAMBERT T., DARCHAMBEAU F., BOUILLON S., ALHOU B., MBEGA J.D., TEODORU C.R., NYONI F.C., MASSICOTTE P., BORGES A.V. Landscape control on the spatial and temporal variability of chromophoric dissolved organic matter and dissolved organic carbon in large African rivers. Ecosystems. 18 (7), 1224, 2015.

7. SHAO T., SONG K., DU J., ZHAO Y., DING Z., GUAN Y., LIU L., ZHANG B. Seasonal variations of CDOM optical properties in rivers across the Liaohe Delta. Wetlands. 1, $1,2015$.

8. SONG K.S., ZANG S.Y., ZHAO Y., LI L., DU J., ZHANG N.N., WANG X.D., SHAO T.T., GUAN Y., LIU L. Spatiotemporal characterization of dissolved carbon for inland waters in semi-humid/semi-arid region, China. Hydrology and Earth System Sciences. 17 (10), 4269, 2013.

9. ZHOU Y., ZHANG Y., SHI K., NIU C., LIU X., DUAN H. Lake Taihu, a large, shallow and eutrophic aquatic ecosystem in China serves as a sink for chromophoric dissolved organic matter. Journal of Great Lakes Research. 41 (2), 597, 2015

10. KAUSHAL S.S., GROFFMAN P.M., MAYER P.M., STRIZ E., GOLD A. J. Effects of stream restoration on denitrification in an urbanizing watershed. Ecological Applications. 18 (3), 789, 2008

11. STANLEY E.H., POWERS S.M., LOTTIG N.R., BUFFAM I., CRAWFORD J.T. Contemporary changes in dissolved organic carbon (DOC) in human-dominated rivers: is there a role for DOC management? Freshwater Biology. 57 (s1), 26, 2012.

12. WILLIAMSON C.E., BRENTRUP J.A., ZHANG J., RENWICK W.H., HARGREAVES B.R., KNOLL L.B., OVERHOLT E.P., ROSE K.C. Lakes as sensors in the landscape: optical metrics as scalable sentinel responses to climate change. Limnology and Oceanography. 59 (3), 840, 2014.

13. GREENWALD M.J., BOWDEN W.B., GOOSEFF M.N., ZARNETSKE J.P., MCNAMARA J.P., BRADFORD J.H., BROSTEN T.R. Hyporheic exchange and water chemistry of two arctic tundra streams of contrasting geomorphology. Journal of Geophysical Research: Biogeosciences. 113 (G2), 2008.

14. LIN C., HE M., ZHOU Y., GUO W., YANG Z. Distribution and contamination assessment of heavy metals in sediment of the Second Songhua River, China. Environmental Monitoring and Assessment. 137 (1), 329, 2008.

15. LEVSHINA S.I., EFIMOV N.N., BAZARKIN V.N. Assessment of the Amur River ecosystem pollution with benzene and its derivatives caused by an accident at the chemical plant in Jilin City, China. Bulletin of environmental contamination and toxicology. 83, 776, 2009.

16. LI S., ZHANG J., MU G., HA S., SUN C., JU H., ZHANG F., CHEN Y.N., MA Q. Optical Properties of Chromophoric Dissolved Organic Matter in the Yinma River Watershed and Drinking Water Resource of Northeast China. Polish Journal of Environmental Studies. 25 (3), 2016.

17. Environmental quality standards for surface water (GB 3838-2002). Available at: http://kjs.mep.gov.cn/ hjbhbz/bzwb/shjbh/shjzlbz/200206/t20020601_66497. shtml. Accessed June 1, 2002.

18. BRICAUD A., MOREL A., PRIEUR L. Absorption by dissolved organic matter of the sea (yellow substance) in the UV and visible domains. Limnology and Oceanography. 26 (1), 43, 1981

19. SMITH R.C., BAKER K.S. Optical properties of the clearest natural waters $(200-800 \mathrm{~nm})$. Applied optics. 20 (2), 177, 1981

20. WEISHAAR J.L., AIKEN G.R., BERGAMASCHI B.A., FRAM M.S., FUJII R., MOPPER K. Evaluation of specific ultraviolet absorbance as an indicator of the chemical composition and reactivity of dissolved organic carbon. Environmental science \& technology. 37 (20), 4702, 2003.

21. D‘SA E.J., GOES J.I., GOMES H. Absorption and fluorescence properties of chromophoric dissolved organic matter of the eastern Bering Sea in the summer with special reference to the influence of a cold pool. Biogeosciences. 11 (12), 3225, 2014

22. WEN Z.D., SONG K.S., ZHAO Y., DU J., MA J.H. Influence of environmental factors on spectral characteristic of chromophoric dissolved organic matter $(\mathrm{CDOM})$ in Inner Mongolia Plateau, China. Hydrology \& Earth System Sciences Discussions. 12 (6), 5895, 2015.

23. ZHANG Y., ZHANG E., YIN Y., VAN DIJK M. A. FENG L., SHI Z., LIU M., QIN B. Characteristics and sources of chromophoric dissolved organic matter in lakes of the Yungui Plateau, China, differing in trophic state and altitude. Limnology and Oceanography. 55 (6), 2645 , 2010.

24. TWARDOWSKI M.S., DONAGHAY P.L. Photobleaching of aquatic dissolved materials: Absorption removal, spectral alteration, and their interrelationship. Journal of Geophysical Research: Oceans. 107 (C8), 2002.

25. YU H., QU F., SUN L., LIANG H., HAN Z.S., CHANG H.Q., SHAO S.L., LI G.B. Relationship between soluble microbial products (SMP) and effluent organic matter (EfOM): characterized by fluorescence excitation emission matrix coupled with parallel factor analysis. Chemosphere. 121, 101, 2015.

26. RAYMOND P.A., MCCLELLAND J.W., HOLMES R.M., ZHULIDOV A.V., MULL K., PETERSON B.J., STRIEGL R.G., AIKEN G.R., GURTOVAYA T.Y. Flux and age of dissolved organic carbon exported to the Arctic Ocean: A carbon isotopic study of the five largest arctic rivers. Global Biogeochem Cycle. 21 (4), 2007.

27. ISHII S.K., BOYER T.H. Behavior of reoccurring PARAFAC components in fluorescent dissolved organic matter in natural and engineered systems: a critical review. Environmental science \& technology. 46 (4), 2006 , 2012.

28. BREZONIK P.L., OLMANSON L.G., FINLAY J.C., BAUER M.E. Factors affecting the measurement of CDOM by remote sensing of optically complex inland waters. Remote Sensing of Environment. 157, 199, 2015.

29. JIAO K.W., LI F.X., ZHOU Q.X. Spatial distribution and pollution level evaluation of nutrients in the Songhua 
River Basin. Journal of Agro-Environment Science. 34, 769, 2015.

30. KALBITZ K., SOLINGER S., PARK J.H., MICHALZIK B., MATZNER E. Controls on the dynamics of dissolved organic matter in soils: a review. Soil Science. 165 (4), 277, 2000.

31. GREGORIC E.G., ROCHETTE P., MCGUIRE S., LIANG B.C., LESSARD R. Soluble organic carbon and carbon dioxide fluxes in maize fields receiving spring-applied manure. Journal of Environmental Quality. 27 (1), 209, 1998.

32. FROST P.C., LARSON J.H., JOHNSTON C.A., YOUNG K.C., MAURICE P.A., LAMBERTI G.A., BRIDGHAM S.D. Landscape predictors of stream dissolved organic matter concentration and physicochemistry in a Lake Superior river watershed. Aquatic Sciences. 68 (1), 40, 2006.

33. JIANG R., HATANO R., ZHAO Y., KURAMOCHI K., HAYAKAWA A., WOLI K.P., SHIMZU M. Factors controlling nitrogen and dissolved organic carbon exports across timescales in two watersheds with different land uses. Hydrological processes. 28 (19), 5105, 2014.

34. FELLMAN J.B., D'AMORE D.V., HOOD E., BOONE R.D. Fluorescence characteristics and biodegradability of dissolved organic matter in forest and wetland soils from coastal temperate watersheds in southeast Alaska. Biogeochemistry. 88 (2), 169, 2008.
35. BUFFAM I., GALLOWAY J.N., BLUM L.K., MCGLATHERY K.J. A stormflow/baseflow comparison of dissolved organic matter concentrations and bioavailability in an Appalachian stream. Biogeochemistry. 53 (3), 269, 2001.

36. SHURPALI N.J., VERMA S.B., KIM J., ARKEBAUER T.J. Carbon dioxide exchange in a peatland ecosystem. Journal of Geophysical Research: Atmospheres. 100(D7), 14319, 1995.

37. LIU M., YU W.T., JIANG Z.S., ZHAO X. Influencing Factors and Ecological Effects of Dissolved Organic Carbon in Soil. Chinese. Chinese Journal of Soil Science. 4, 030, 2007.

38. HEINZ M., GRAEBER D., ZAK D., ZWIRNMANN E., GELBRECHT J., PUSCH M.T. Comparison of organic matter composition in agricultural versus forest affected headwaters with special emphasis on organic nitrogen. Environmental science \& technology. 49 (4), 2081, 2015.

39. DELPRAT L., CHASSI P., LINERES M., JAMBERT C. Characterization of dissolved organic carbon in cleared forest soils converted to maize cultivation. Developments in Crop Science. 25, 257, 1997.

40. WILSON H.F., XENOPOULOS M.A. Ecosystem and seasonal control of stream dissolved organic carbon along a gradient of land use. Ecosystems. 11 (4), 555, 2008. 
